\title{
FROM PLANNING TO PRACTICE: IMPLEMENTATION CHALLENGES FOR SOUTH AFRICA'S PROPOSED LANGUAGE POLICY AND PLAN'
}

\author{
(Based on the Final Draft of the White Paper, dated 29 February 2000)
}

1

Laurence Wright

Institute for the Study of English in Africa

Rhodes University

The article sets out to challenge the tendency of language policy to rest in the comfort zone of language planning, and argues that South Africa has reached the stage where such planning must be accompanied by vigorous cultivation initiatives, without which the new language policy will fall into disrepute or desuetude. Having located the proposed policy in relation to the typology established by Fishman [1969], the article goes on argue that its primary thrust is to ensure that, wherever possible, in official interactions people are addressed in their own languages, receive services in their own languages and can respond in their own languages. However, the article criticises the complex rotation systems set out for official documents in the eleven official languages, suggesting that direct economic costs and administrative complexity have been insufficiently considered. A trend towards increased language coercion is identified, in marked contrast to the original LANGTAG report. Stressing the need for practical language cultivation initiatives, the article puts forward priorities for developing the PMLs, and urges that greater emphasis be placed on language development in communities of practice to complement the usual measures taken to institutionalise neglected languages. The establishment of regional language development centre is proposed.

In die artikel word die neiging van die taalbeleid om in die gemaksone van taalbeplanning te rus, bevraagteken. Daar word beweer dat Suid-Afrika ' $n$ stadium bereik het waar sodanige beplanning vergesel moet word van daadkragtige bevorderingsinisiatiewe waarsonder die nuwe taalbeleid in onguns of onbruik sal verval. Die voorgestelde beleid word eerstens in verhouding geplaas tot dietipologie wat deur Fishman[1969] daargestel is. Daarna word aangevoer dat dit die hoofdoelwit daarvan is om te verseker dat mense in amptelike interaksies vir sover moontlik in hul eie tale dienste ontvang en in hul eie tale daarop kan antwoord. Kritiek word egter uitgespreek oor die ingewikkelde roteringstelsels wat vir amptelike dokumente in die elf ampstale uiteengesit word. Daar word beweer dat onvoldoende ag geslaan is op die regstreekse ekonomiese kostes en administratiewe ingewikkeldheid daarvan. In sterk kontras met die oorspronklike LANGTAG-verslag word hierin ' $n$ neiging tot toenemende taaldwang bespeur. Deur die behoefte aan prakties uitvoerbare taalbevorderingsinisiatiewe te beklemtoon, word prioriteite uiteengesit waarvolgens die voorheen gemarginaliseerde tale ontwikkel kan word. Daar word daarop aangedring dat groter klem gelê word op taalontwikkeling binne die gemeenskappe wat die tale besig om sodoende die gebruiklike maatreëls vir die amptelike vestiging van verwaarloosde tale aan te vul. Daar word voorgestel dat streeks-taalontwikkelingsentra daargestel word. 
This article is a brief appeal to look beyond the prescriptions of 'top-down' language planning towards greater emphasis on targeted issues of grass-roots, community and specialised language cultivation.

Speaking from international experience, Kaplan and Baldauf argue that 'most of the traditional participants in language policy and planning have come from 'top-down' language planning situations' where 'people with power and authority make language-related decisions for groups, often with little or no consultation with the ultimate language learners and users' (1997: 196).

That language planning under the old South African regime was habitually undertaken in this mode can be taken for granted. What is more surprising is that so much of the initial work of synthesis which culminated in the 1996 LANGTAG (Language Planning Task Group) report seems to have followed a similar route sidelining language cultivation issues in favour of the more immediate tasks of language planning. The preamble to the report quotes Jernudd and Das Gupta with approbation, describing the so-called 'canonical model' of language planning as follows:

The broadest authorization of planning is obtained from the politicians. A body of experts is then specifically delegated the task of preparing a plan. In preparing this, the experts ideally estimate existing resources in terms of development targets. Once targets are agreed upon, a strategy of action is elaborated. These are authorised by the legislature and are implemented by the organisational set-up authorised in its turn by the planning executive... In these ideal processes, a planning agency is charged with the over-all guidance...

(1975: 196)

What is in question here is not the legitimacy of the South African process. The language planning scenario has been part and parcel of the liberation struggle virtually since the 1976 Soweto uprisings. What we do need to be alert to is the tendency of language policy to rest in the comfort zone of language planning, rather than move boldly into the only arena which can realise the ends of language planning, namely practical initiatives in language cultivation.

Given this tendency to postpone engagement with language cultivation issues, the draft White Paper and Plan for South Africa (handed to Minister Ngubane as a draft Bill during the September 2000 Heritage Day celebrations in Pietersburg, Northern Province) constitutes a bold attempt to supply a degree of implementational credibility and impetus to the process of making the new language dispensation a reality. Backed by the timeous release of the Pan South African Language Board (PANSALB) report on language use (7 September 2000) these two interventions begin, together, to lend substance to the bald outline of language policy with which the general public has been living since the new constitution was achieved.

Much of the language-planning process leading up to the promulgation of the National Language Policy has been driven by the need to alert the nation to what has been dubbed 'the dangerous power of English'(de Kadt: 1993), specifically in relation to continued suppression or even diminution of the PMLs (Previously Marginalised Languages). From the standpoint of developing the PMLs, this has been a thoroughly necessary exercise which has resulted in steering South Africa towards an unprecedented category ' $D$ '-type policy decision in trying to achieve its envisioned language dispensation. 
What is a category ' $D$ ' decision? It will be recalled that during the first flush of language policy responses to the decolonisation process of the early 1960s, Joshua Fishman did some pioneering work on national language planning, and distinguished 3 types of response.

Type A decisions, where the power elite (to use C. Wright Mills's term) chose a language of wider communication as the national language were, he believed, a consequence of those in power not being able to perceive the presence of a valued and coherent socio-cultural heritage capable of unifying the nation, coupled with an urgent need to achieve a degree of immediate socio-political coherence. Typically, these judgments resulted in the relatively uncontested adoption of a former colonial language as the national or official language. Local and regional languages tended, in these cases, to be valued as merely convenient for immediate instrumental purposes of local communication and cultural identity. Fishman called this type of decision language planning in the service of nationism. 'Nationism - as distinguished from nationalism - ', he said, 'is primarily concerned not with ethnic authenticity but with operational efficiency'(1972:194).

Type B decisions are very different. Here, the language planners are in touch with what is perceived as an authentic national tradition embodying indigenised laws, values, beliefs, artforms, histories, tales of heroism and so forth, capable of unifying the nation. They also have available a single dominant indigenous (or indigenised) language to serve as a national language. The two, language and tradition, are perceived as inseparably linked. In this case, the obvious decision is to confirm the indigenous language as the bearer of national ideals and prestige, while any language of wider communication is seen as a temporary necessity, to be phased out as the indigenous prestige language is modernised and elaborated to the point where it can carry the full burden of national life. ${ }^{2}$

Type $\mathrm{C}$ decisions tend to be elicited when there is in fact a multiplicity of valued traditions within the polity, each of them dear to some social grouping. These groupings are perceived to be politically strong enough to impact on the cohesion of the nation, and to have sufficient internal coherence - their own prized histories and traditions - to achieve their own degree of integration. Obviously, selection of any one of the languages of these speech communities as a national language would disadvantage members of the other communities. In consequence, as Fishman puts it:

In order to avoid giving any party an advantage - and in order to avoid constant rivalry for national prominence among the various contenders - a foreign Language of Wider Communication is frequently selected de jure or utilized de facto as (co-) official or as working language (W) at the national level (sometimes in conjunction with an indigenous national language which may actually be little employed by those who are ostensibly its guardians).

(1972:204)

Now clearly South Africa is, on paper at least, going for something slightly different - Type ' $C$ ' language policy of a kind, with multiple official languages, but without an institutionalised 'Language of Wider Communication'. Let us call this a Type ' $D$ ' decision.

It is a very interesting response to our rich linguistic heritage. Clearly, the emphasis is on long-range thinking, and a preference for cultural authenticity over short-term socio-cultural integration and operational efficiency - the driving force behind type ' $A$ ' decisions, as we have seen. The approach may not be consonant with the country's drive for modernisation in 
response to the immediate pressures of globalisation, but it is not, as far as I can see, utterly inhospitable to questions of efficiency, merely concerned to tackle them in the long term.

For example, the Introduction to the White Paper indicates that this new language policy

is making its appearance at a decisive point in history, when public and private institutions are taking ad hoc language decisions that tend to negate the constitutional provisions and requirements relating to language. This situation is directly linked to ongoing language domination and widespread, but short-sighted, bureaucratic attitudes against implementing multilingualism.

An index to this comment may be the recent court cases in which PANSALB has challenged the 'English only' practice of some South African bureaucracies (see, for example, the impending 'Language war' in Bloemfontein over issuing municipal accounts only in English, as reported in the Cape Argus). ${ }^{3}$ Now clearly there is an enormous advantage to having one operational language within a large organisation. Imagine never knowing in which of eleven possible languages you are going to be spoken to, or be required to respond in, on the telephone! Even when softened by a possibly more limiting provincial language policy, the challenges are formidable.

However, when looked at more closely, it is noticeable that the primary thrust of the proposed National Language Policy is not designed to crimp internal communicative efficiency within an organisation, but to ensure that the target groups served by government structures, bodies supported by government, and the private sector, are addressed in their own languages, receive services in their own languages, and can respond in their own languages. ${ }^{4}$ This is an entirely reasonable and admirable goal, though immensely difficult of accomplishment.

Internally, government structures are given considerable lee-way to agree their working languages for internal oral and written communication (with the somewhat overwhelming proviso that 'no person shall be prevented from using the language of his or her preference, at any given time' (2000:13)). Externally, they must respond in the languages chosen by the citizenry (2000:13).

Of course multilingualism places demands on communication. The limits of linguistic choice on internal written and oral communication are established by cases where 'other rules apply' $(2000: 13)$. Obviously one such case occurs where all eleven official languages are required to be used. These 'other rules' are also expressed in the controversial rotation systems for official documents. A colleague reports that at the Language Indaba in KwaZulu-Natal in March 2000, during which the rotation system was first unveiled, there was an immediate outcry from participants demanding that all eleven languages be used without fear or favour. It had to be pointed out that very serious economic constraints had to be met, before delegates would countenance any form of rotation system at all. ${ }^{5}$

Of the two systems proposed, Option 2 - a later introduction following controversy surrounding Option 1 - though somewhat more expensive, seems the more rational.

Option 1 offers rotation within four language groups composed as follows: 
- Nguni group (isiNdebele, isiZulu, siSwati. IsiXhosa)

- Sotho group (Sepedi, Sesotho, Setswana)

- Tshivenda/ Xitsonga

- English/Afrikaans

Documents must be produced in 4 versions, one from each of the groups, with the languages within each group being chosen on a rotational basis. Thus English and Afrikaans would alternate in subsequent documents, Tshivenda and Xitsonga would do the same (at least for the next 5 to 10 years, after which they are to be 'uncoupled' (2000:11)); Sepedi, Sesotho and Setswana would each appear in every third document, while isiNdebele, isiZulu, siSwati and isiXhosa. would each appear in every fourth document.

(One must spare a thought here for the Office Managers who have to track each document through the translation system!)

Option 2 is more promising, and does away with the nonsense linkage between Tshivenda and Xitsonga from the outset, giving them separate status; decouples Afrikaans and English; and then applies the rotation principle within the Nguni group and the Sotho group, respectively. This means six translations of every document rather than four; but it does comply rather better with the demands of linguistic rationality. There is a degree of intercomprehensibility within the Sotho and Nguni groups; Tshivenda and Xitsonga stand on their own; and we no longer have to assume continued Afrikaans/English bilingualism, a legacy of the past, in order to make the system work (2000:11). A further advantage is that an English version is always available, which is a consideration for international accessibility and communication.

This policy is to be policed using a code of conduct (as envisioned in the original LANGTAG report) which will apply to public servants, and to those employed by bodies supported by government. The code provides for 'disciplinary measures in cases of transgression' $(2000: 16)$. The private sector is to be encouraged to 'develop and implement their own language policies in consonance with the framework of this language policy' (2000:17).

The element of coercion deviates from the optimism of the LANGTAG report, which held that:

Persuasion, encouragement and incentives rather than coercion are the appropriate policy stances in the highly sensitive area of language practices and language usage.

No person should be compelled to learn or to use any language.

(1996:13)

Undoubtedly some of the countervailing forces which this measure sets out to address are the entrenched power of Afrikaans in the civil service and the prestige, ubiquity and popularity of English in South African parliamentary, business and financial circles. The issue is whether a coercive language planning approach is appropriate, practical or adequate to counter these sociolinguistic forces.

One can see that every effort has been made in the policy document to stick to what I have called a Type ' $D$ ' decision: a number of official languages (in our case eleven) enjoying 
parity of status and equity in use. The policy points towards an exciting and bold vision of South Africa's emerging identity - one in which very different collective histories are neither deflected nor suppressed but allowed to join and inform the mainstream of national life. What is more questionable is the social will and the executive ability to achieve this goal. To do so requires steady application and a shared vision among all those within a particular communication system. The costs, both financial and organisational, are enormous. Have these been estimated?

Fishman's work preceded the South African debate by some twenty years. Would he have regarded the South African decision as belonging to a unique category? This seems unlikely. $\mathrm{He}$ would probably have placed South Africa as a sub-category within Type ' $\mathrm{C}$ ' decisions because, observing from an academic perspective rather than an ideological one, he would have recognised the de facto role which English plays, and will continue to play, in our national life as a 'Language of Wider Communication' (in his terminology), or a language of national communication, in mine (see 1993:10). Clearly, under the envisaged language policy, English will never be endorsed as an official language of national communication; but de facto, that will probably be its role for the foreseeable future.

This leaves our soon-to-be-enacted language legislation in a dangerously ambiguous position; unless, of course it is substantially emended in the legislature. The policy is predicated on the future achievement of a desired state of effective language equity. To even begin to work towards that state requires mobilising considerable financial and human resources. We come from a history of rebellion against enforced language engineering. In not recognising the special role of English in the nation, a role not enforced but chosen, the policy runs counter to current and emerging practice, and to the thrust of a large portion of informal public opinion (however under-informed this may be in matters of linguistic ecology). ${ }^{7}$ The gap between legislative force and practical implementation is usually bridged by enlisting popular sentiment, which at present - extrapolating from recent micro-research (see papers by Barkhuizen and de Kadt), as well as from experience elsewhere in Africa - is by no means solidly behind the thrust of the White Paper. One inference must be either that we are moving into an era of possible further language coercion on a grand scale, or, more likely, into an era where language policy is more honoured in the breach than in the observance.

In his book on English as a Global Language (1997), David Crystal makes a typically cautious but accurate prognostication about South Africa's new language dispensation:

The consequences of such an ambitious language policy remain to be seen, but the difficulties of administrating an eleven-language formula are immense, and it is likely that English will continue to be an important lingua franca.

(1997:40)

That the possible dominance of English had to be countered looks to have been a major consideration throughout the post-1990 language policy development process in South Africa. The potential advantages of having English as one of the 'voices of the land'- to borrow Jeremy Cronin's phrase (Cronin, 1983: 58) - receive hardly a mention in the LANGTAG documents. This is unsurprising, since the object of the process was to re-think the language conundrum with a view to re-asserting the value of our indigenous languages. However, policy prescription has its limitations, both financial and sociolinguistic. Without favourable sociolinguistic conditions, even well-financed language policy declines into ideological wish-fulfilment. 
In particular, we need to be cautious about raising false expectations about the ease with which the PMLs can effectively be elaborated to carry the so-called higher functions in modern society. There is some highly disingenuous argument on this point in the LANGTAG report. For example, Randolph Quirk (Quoted in Stanley, Ingram \& Chittick, 1990:48) is put forward as holding that 'those countries which use English as a first language are disadvantaged' - using here the instance of scientific publication in French:

It so happens that in France 56 per cent of scientific publication is in English. But this still leaves 44 per cent that is not and I wonder how many of our [British] scientists bother to read or are capable of reading that 44 per cent. By contrast it must be evident that in France, every scientist reads not only the 44 per cent that is already in his or her own language but additionally the 56 per cent that is in ours. So the losers are of course ourselves.... If 45 per cent of the World's relevant publications is in English, it follows as the night the day that 55 per cent is not.... In short the result of English being the chief language of science is that virtually every scientist on earth is better informed than the scientist whose native language is English: because we are the people who by and large see no need to learn any other.

(1996:100)

Quirk's polemic against English-speaking linguistic insularity is here turned into a very misleading view of linguistic hegemony in the scientific world. A recent article by Burton Bollag in The Chronicle of Higher Education points out that 'Ninety-five percent of the 925,000 scientific articles published in thousands of major periodicals in 1997 were written in English' and that 'only half of the English articles originated in English-speaking countries'. Moreover, the situation in France has changed dramatically in the ten years following the publication in which Quirk is quoted:

In 1990 , according to the publishers of the Science Citation Index, 30.6 percent of scientific papers from France were published in French - the rest in English. By 1999, the portion in French had halved, to 16.2 per cent. French scientific conferences are now frequently conducted in English, a development that, in the early 1990s, prompted the authorities to threaten to withdraw government money from meetings held in France and not conducted mainly in French. The threat had virtually no effect.

The case of France is worth dwelling on, for if ever there were a country devoted to propping up the status of its wonderful language within its own borders and in the world, and with the resources to do so, it is France. If France cannot sustain the linguistic hegemony of French among her own scientists - a language that is fully elaborated for use at the highest levels of abstraction and conceptual precision - can it be appropriate to place that particular burden on the South African PMLs? Far better to decide to tackle the urgent issues surrounding basic scientific and mathematical understanding in the PMLs for the foundation phase of our education system.

Priorities must be established. My own would be:

1. Development of the PMLs in the foundation phase of the education system.

2. Development of literature, publication and reading in the PMLs.

3. Capture and documentation of oral history and indigenous knowledge systems. 
4. Development and institutionalisation of PMLs for community medicine, psychiatry and law.

The most tragic language planning outcome of all would be for South Africa's limited human and financial resources to be wasted in attempting things of little consequence for the country's future, while the rich cultural heritage carried by the PMLs is dying on the ground. We need to take tough decisions about what can in fact be achieved with the resources available, and do that vigorously and consistently. The White Paper offers a smorgasbord of possibilities, some of which belong with the fairy on the Christmas tree ${ }^{8}$ others are realisable. It's a question of choosing which aspects of policy to move on and in what sequence. We cannot pretend that the White Paper will implement itself.

\section{POLICY EQUALS PLANNING PLUS CULTIVATION}

The reason is that top-down language planning (and all language planning, however conscientious the process of prior consultation has been, ends up being top-down) must be complemented by a vigorous, innovative programme of targeted community language cultivation if the PMLs are to take their proper place in the language ecology of the country. Following Neustup (1970), language policy has two major components: language planning and language cultivation. South Africa is reaching the critical stage where language planning must be accompanied by vigorous cultivation initiatives without which the whole language planning exercise may fall into disrepute or desuetude.

For instance, a major factor inhibiting the development of the PMLs in our type of language situation is the lack of adequate social motivation to drive the cultivation process. Languages are developed by people within communities of practice. If people undervalue their own languages or, even worse from a developmental point of view, can see no immediate use for them, then there is very little that government-initiated strategies and resources can achieve.

This is a matter of vital importance. Throughout much of post-colonial Africa, development of PMLs has been conditioned by two factors: economic constraints and an absence of strong social motivation. The tendency has been for government to tackle the obvious and manageable top-down tasks: development of technical terminology, provision of dictionaries, encouragement of relevant text-book production, promotion of media in indigenous languages, official language awareness campaigns, and so on.

The all too usual outcome has been artificial and under-utilised terminologies, dictionaries, text-books: unread (and unsold!) literature; and further polarisation of intellectual life along the urban-rural continuum. Typically, the economic language resources of post-colonial Africa have been almost wholly absorbed by pursuing these worthy and necessary aspects of language development. The results in terms of language development and modernisation on the ground have been somewhat disappointing.

South Africa must avoid becoming constrained by a similar approach. That there are other, complementary, possibilities under consideration is evident in the draft White Paper where Section 5, the Implementation Plan, makes provision for the kinds of intervention classified as language cultivation. Section 5.4 'Language awareness campaigns', and section 5.7 'Development of African Languages', open a space for the concept of targeted, participatory language development put forward here. Such measures were envisaged in the LANGTAG 
report, but relegated to the category of 'Long-Term Measures'(1996:5). My point is, we must move on this now.

As we are well aware, English has become a language of power in the first instance because of the history of conquest and trade which lies behind it; but more significantly from our present perspective, because it is well-resourced, has been used in many different contexts at a high level of technical elaboration, and because its acquisition promises a large measure of instrumental value, social prestige and economic success. In other words, there is powerful social motivation behind the acquisition and elaboration of English.

Afrikaans developed because resources were poured into the process, and social motivation was secured by hitching the language to the socio-political bandwagon of Afrikaner Nationalism. That this particular motivation was less than adequate in the long term is evident from the crisis through which the language is now passing - though I have little doubt that it is a crisis from which it will emerge with considerable resilience.

To develop the PMLs, therefore, means must be found to stimulate the social motivation which will not only secure their cultural significance, but lead to steady modernisation within a practising language community. Only when the top-down prescriptions of language policy mesh with the linguistic and cultural energies of the speech communities concerned in deliberate strategies, can language development be said to be taking place.

This is by no means easy. The initiatives we can afford, and the level of language activism in the country available to implement them, are so modest that an insurmountable gap opens up between the full vision embodied in the White Paper and the probable evolution of South African language practice.

It is politically and economically unwise to attempt to impose a policy which runs counter to the trend of emerging national practice, unless the polity as a whole can be persuaded of its centrality, and unless the financial and human resources are available to ensure its success. Neither of these conditions pertains in South Africa at the moment.

Yet the abstract faith in language planning as the be-all and end-all of language policy lingers on. Let me give an example. During the 1998 African Renaissance conference, Diale Diop argued as follows:

The resort to African languages in institutional life is not only the condition for an efficient promotion of those languages, but also for rapid and massive development of literacy, which would allow the widespread dissemination of basic education and the re-entrenchment of science to take place in Africa.

Note that the institutional use of African languages is presented as the condition - not $a$ condition - the condition, for the promotion of African languages, after which all manner of good things follow in consequence. Clearly he means an enabling condition and not a causal one. Nevertheless, the message is, 'First establish the institutional use of the PMLs and, not without effort, their broader development must follow.'

Here we must be cautious. Certainly the intention of the provisions in the White Paper can be supported: the presence of the PMLs in institutional life will send an unmistakable socio- 
political signal to South African society that multilingualism is, or should be, functional within the developed parts of the South African economy, and not be limited to interaction with target commercial or industrial markets and suppliers.

But still we are confronted with what must be taken as an article of faith: the belief that this kind of statutory provision will, more or less naturally, encourage the development of multilingualism; for instance, in the legislature. To quote the LANGTAG report once more:

If Acts of Parliament are translated into the marginalised languages the concomitant subordinate legislation will also be translated, as well as other documents arising from such legislation. This could potentially unleash a demand for new terms and phrases, resulting in an increased vocabulary and subsequent further elaboration. It could be predicted that people would gradually acquire the habit of reading such texts in their own language, and that as more documents became available in these languages, more people would read them.

(1996: 161)

The passage is unduly optimistic. Questions we must ask include: Is there a substantial pentup demand for parliamentary documents in the PMLs? - particularly when a specific language will appear only on a rotational basis, one whose time-table has yet to be worked out in practice, and subject both to the efficiency of translation services in publishing hard copy, and to the high probability that those with whom the particular document has to be discussed will come from a variety of language backgrounds? Yes, there is demand, but it is in the first instance symbolic demand rather than actual. The policy is principally a gesture designed to make sure that multilingualism takes root in the polity at the highest levels. What follows will depend only marginally on the planned language requirements, and much more on the social prestige generated around use of the PMLs, upon their satisfactory elaboration, and upon achieving a critical mass of users in particular contexts.

Language planning is a necessary but far from sufficient condition for real language development. To make language policy bite, yes, we need to raise the profile of the PMLs through awareness campaigns, but we must back this effort with financial support for directed community programmes which encourage language development in particular speech communities or communities of practice, be these professional groupings, trade associations, rural writers groups, publishing initiatives, reading circles, curriculum development teams, oral history projects, science awareness projects, film and television initiatives, and so forth. To coordinate and initiate this kind of activity in a focused way, it seems necessary that there should be a language centre for each of the official languages of South Africa, charged with the task of ensuring that the language planning provisions of National Language Policy are followed by genuine language cultivation initiatives, appropriate to the state of development of the language concerned. The coordinating role needs only a small staff of competent language activists and practitioners, based in the centre of the speech community concerned, to make a significant start. ${ }^{9}$ To those who point to the economic cost of developing the PMLs we reply, try calculating the cultural and political cost of not developing them.

In conclusion, then, it seems likely that the envisaged development of the PMLs can only be ensured if resources and energy are allocated to their deliberate modernisation and elaboration in real-life contexts. Unless this is done, and probably even if it is done, English is likely to continue to serve as South Africa's de facto language of formal national communication, even if this role is not sanctioned by our new National Language Policy. 
Whether the country is best served by a policy at odds with national practice on this point is debatable.

Joshua Fishman ended his seminal piece on the role of national languages and languages of wider communication as follows:

National languages and Languages of Wider Communication constantly come and go on the world scene. We neither can nor should foresee the time of being able to get along without both. Our need, therefore, both for practical and for academic purposes, is to know the processes and the circumstances through which human decisions influence their adoption, cultivation, displacement and replacement.

([1969]: 207-8)

\section{END NOTES}

${ }^{1}$ A shortened version of this article was delivered during SAALA 2000, at the University of Stellenbosch, 14-16 September 2000.

${ }^{2}$ A similar attitude has on occasion been expressed in South Africa. For instance, the Chairperson of the LANGTAG process, Neville Alexander, has from the outset tried to foresee a day when English no longer plays its role as an indispensable yet obviously imperfect lingua franca:

Since the majority of our people are mother-tongue speakers of one or other indigenous African language, it is more than likely that another lingua franca may eventually replace English in this function for internal purposes and that English will remain no more than a language of wider communication in an international sense.

This begs many of the questions involved in the politics of language choice, and which have influenced the development of policy for South Africa (see the discussion of Type ' $C$ ' and Type ' $D$ ' decisions, below), while at the same time overestimating the power of policy to counter the attractions of a global language like English.

${ }^{3}$ The 'language war' report in the Cape Argus starts:

The Bloemfontein city council could face legal action over its decision to issue municipal accounts only in English, says Pan South African Language Board's senior legal adviser, Christa Roodt.

She said the board might seek a high court order compelling the municipality to issue accounts in at least two of the official languages most widely used by clients.

It seems likely that this is a case fuelled largely by justified discontent amongst Afrikaans speakers, rather than from the PMLs. The report doesn't say. Other comparable cases have involved the Post Office, and more will no doubt follow.

${ }^{4}$ See particularly sections 4.1 to 4.4 . The aim of these sections is more easily realised in rural areas with a degree of linguistic homogeneity, than it is in the scrambled linguistic melting pots of South Africa's urban regions, where English is likely to be the lingua franca for official interaction.

s Informant: Malcolm Hacksley.

6 The LANGTAG report has much to say about multilingualism as an economic resource; virtually nothing about its economic costs. The report was preceded by language planning report 5.2, The Economics of Language, in which among other things it was argued that CBA (cost benefit analysis) was inappropriate as a means of assessing the economic viability of language policy. Given the abstract and incalculable benefits of language this is surely true. However, there are rather heavy direct cost implications. and as soon as the new Language Policy proposals become more widely debated in public, those upon whom the burden of paying for 
the policy falls will doubtless become very vocal and extremely explicit about the costs involved. The government may well be caught flat-footed unless clear answers are available in this area.

The one-sided views expressed in the LANGTAG report (see Chapter 6, section 3.3: 'The assumption that multilingualism engenders excessive public expenditure') simply will not do.

${ }^{7}$ See, for example, the piece by Fred Malherbe, 'Traditional languages go belly up,' in The Star Tonight, in which he writes:

It's ironic that despite all the talk (in English) of an African renaissance we are hearing the death-rattle of the deepest link the African people have with their past - their languages.

The view is commonplace among members of the urban elites.

${ }^{8}$ An instance of unrealistic aspiration in the White Paper is the following stipulation in regard to '4.9 Mandated Public Media':

In regard to television, an increasing amount of broadcasting airtime shall be progressively provided for the African languages and Sign Language/s, up to a point where all official South African languages are accorded an equitable proportion of airtime.

The public service provided by the corporation must strive to be of high quality in all of the languages used.

Even when due emphasis is placed on 'equity' rather than 'equality', the ultimate aim is utopian to a degree that calls in question the seriousness of the aspiration. The result certainly presents a mandate for directed effort which is one important feature of policy statements - but the goal is so high that the practical contingencies are left out of account.

"See the document, 'Language Development in South Africa: A Way Forward, compiled by Laurence Wright and Malcolm Hacksley, and submitted to the DACST in February 2000.

The opening of The African Languages Literary Information Museum at UNISA (which took place on Sept. 26,2000 ), while signalling a step forward, tends to stymie the urgent necessity to locate language development agencies where they can be used to attract the interest, loyalty and support of speakers of the languages. In order to maximise their developmental impact, the country needs to move away from the plethora of centralised, Pretoria-based language agencies towards direct interaction with communities of practice.

\section{REFERENCES}

THE ADVISORY PANEL TO THE MINISTER OF ARTS CULTURE SCIENCE AND TECHNOLOGY.* 2000. Language policy and plan for South Africa. Pretoria: Department of Arts, Culture, Science and Technology. (* Neville Alexander, Zubeida Desai, Nhlanhla Maake, Langa Mathenjwa, Dumisane Nthsangase, Hennie Strydom): 1-21.

ALEXANDER, NEVILLE. 1989. Language policy and national unity in South AfricalAzania. Cape Town: Buchu Books.

BARKHUIZEN, GARY. 2000. Xhosa first-language teaching and learning: Boring and difficult? You may be surprised! Paper presented at SAALA 2000, University of Stellenbosch, 14-16 September 2000. 
BOLLAG, BURTON. The New Latin: English dominates in academe. The Chronicle of Higher Education. September 8, 2000. http://chronicle.com/free GOTOBUTTON BM1.

CRONIN, JEREMY. 1983. To learn how to speak. In Inside. Johannesburg: Ravan: p. 58.

CRYSTAL, DAVID.1997. English as a global language. Cambridge: Cambridge University Press.

DIOP, DIALE. 1998. Africa: Mankind's future. In Makgoba, Malegapuru W (Ed.), African Renaissance: The new struggle. Cape Town: Mafube.

DE KADT, ELIZABETH. 1993. The dangerous power of English. In Young, Douglas (Ed.) How do we ensure access to English in a Post-Apartheid Southern Africa? Proceedings of the English Academy Conference held at the University of Cape Town 1-3 July 1993: 6-16.

DE KADT, ELIZABETH. 2000. Gender aspects in the acquisition of English as a second language. Paper presented at SAALA 2000, University of Stellenbosch, September 2000 .

FISHMAN, JOSHUA A. 1969. National languages and languages of wider communication in developing nations. In Fishman, Joshua, Language in Sociocultural Change: Essays (Edited by Anwar S. Dil). Stanford, CA: Stanford University Press.

JERNUDD, B AND DAS GUPTA, J. 1975. Towards a theory of language planning. In Rubin, J and B Jernudd (Eds), Can language be planned? Sociolinguistic theory and practice for developing nations. Honolulu: The University Press of Hawaii.

KAPLAN, ROBERT B. AND RICHARD B BALDAUF JR.1997. Language planning: From practice to theory. Clevedon: Multilingual Matters Ltd.

Language war looms for Bloem city council. Cape Argus. August 30. 2000: Independent Online. \{ GOTOBUTTON BM_2_www.iol.co.za Sept.19.

[LANGTAG report] Towards a national language policy: Final Report of the Language Plan Task Group. 1996. Pretoria: Department of Arts, Culture, Science and Technology.

MALHERBE, FRED. Traditional languages go belly-up. Star Tonight. 30 August 2000.

MILLS, C WRIGHT. 1956. The power elite. New York, NY: Oxford University Press.

NEUSTUPN, JIRI. 1970. Basic types of treatment of language problems, Linguistic Communications 1:77-98.

STRAUSS, GIDEON, et al. 1996. The Economics of language. Language Planning Report No. 5.2. Pretoria: Department of Arts, Culture, Science and Technology. 
WRIGHT, LAURENCE. 1993. English in South Africa: Effective communication and the policy debate. English Academy Review 10:1-13.

\section{Bibliographic Note}

Lawrence Wright is the Director of the Institute for the Study of English in Africa. He has published widely in the field of literature and also language policy. 